\title{
Fine-ground ceramics as an alternative binder in high performance concrete
}

\author{
E. Vejmelková ${ }^{1}$, M. Ondráček ${ }^{2}$, M. Sedlmajer ${ }^{2} \&$ R. Černý ${ }^{1}$ \\ ${ }^{I}$ Department of Materials Engineering and Chemistry, Faculty of Civil \\ Engineering, Czech Technical University in Prague, Czech Republic \\ ${ }^{2}$ Institute of Technology of Building Materials and Components, Faculty \\ of Civil Engineering, Brno University of Technology, Czech Republic
}

\begin{abstract}
The ceramic industry often produces calcined clays that result from burning illite-group clays, which are commonly used in the production of red-clay ceramic products. A portion of these products (which amounts up to $2 \%$ depending on producer and country) is discarded as scrap, and thus constitutes industrial waste. The residues of ceramic bricks and floor and roof tiles ground to a suitable fineness can become active pozzolans. So, they have the potential to be used in mortar and concrete. In this paper, mechanical properties and heat and water transport parameters of high performance concrete containing fine-ground ceramics as a partial replacement of Portland cement are studied and compared with reference high performance concrete. The experimental results show that the replacement of Portland cement in the amount of $20 \%$ by mass is the most suitable solution. In comparison with reference high performance concrete the mechanical properties of concrete where up to $20 \%$ of cement is replaced by fine-ground ceramics are similar or slightly worse, and water transport properties are still acceptable from the durability point of view.
\end{abstract}

Keywords: high performance concrete, fine-ground ceramics, mechanical properties, water transport properties, thermal properties.

\section{Introduction}

Many industrial byproducts possessing pozzolanic properties are produced in large amounts worldwide, and despite the current trends of environmental protection and sustainable construction, their production volume still greatly 
exceeds their industrial reuse. Therefore, there are compelling reasons to extend the practice of partial replacement of cement in concrete and mortar with waste materials or at least with more environmentally friendly materials from the point of view of $\mathrm{CO}_{2}$ production, which have pozzolanic properties. One possible source for such a pozzolan is calcined clay [1].

The ceramic industry often produces calcined clays that result from burning illite-group clays, which are commonly used in the production of red-clay ceramic products. A portion of these products (which amounts up to $2 \%$ depending on producer and country) is discarded as scrap, and thus constitutes industrial waste. The residues of ceramic bricks and floor and roof tiles ground to a suitable fineness can become active pozzolans [2-4]. Therefore, waste ceramic materials may have the potential to become a cheaper but almost equivalent alternative to metakaolin as a supplementary binder in mortar and concrete.

In this paper, fine-ground ceramics is used as an alternative binder in high performance concrete (HPC), replacing Portland cement in the amount of up to $60 \%$ of mass.

\section{Materials and samples}

The high performance concrete mixtures presented in Table 1 were prepared with Portland cement CEM I $42.5 \mathrm{R}$ as the main binder. The chemical composition of cement is shown in Table 2; its specific surface area was 341 $\mathrm{m}^{2} / \mathrm{kg}$. A part of cement was replaced by fine-ground ceramics with the chemical composition shown in Table 3 . Its specific surface area was $582 \mathrm{~m}^{2} / \mathrm{kg}$.

The measurement of material parameters of hardened concrete mixes was done after 28 days of standard curing. It took place in a conditioned laboratory at the temperature of $22 \pm 1^{\circ} \mathrm{C}$ and $25-30 \%$ relative humidity. The following specimens were used in the experiments: basic physical properties - 6 specimens 50 × 50 × $25 \mathrm{~mm}$, bending strength - 3 specimens $100 \times 100 \times 400 \mathrm{~mm}$, compressive strength -3 specimens $150 \times 150 \times 150 \mathrm{~mm}$, water transport

Table 1: $\quad$ Composition of the studied concretes.

\begin{tabular}{|c|c|c|c|c|c|}
\hline \multirow{2}{*}{ Component } & \multicolumn{5}{|c|}{ Composition $\left[\mathrm{kgm}^{-3}\right]$} \\
\cline { 2 - 6 } & $\mathrm{RC}$ & $\mathrm{RC} 10$ & $\mathrm{RC} 20$ & $\mathrm{RC} 40$ & RC60 \\
\hline CEM I 42.5 R & 484.0 & 435.6 & 387.2 & 304.8 & 193.6 \\
\hline $\begin{array}{c}\text { fine-ground } \\
\text { ceramics }\end{array}$ & - & $\begin{array}{c}48.4 \\
(10 \%)\end{array}$ & $\begin{array}{c}96.8 \\
(20 \%)\end{array}$ & $\begin{array}{c}179.2 \\
(40 \%)\end{array}$ & $\begin{array}{c}290.4 \\
(60 \%)\end{array}$ \\
\hline aggregates 0-4 mm & 812 & 812 & 812 & 812 & 812 \\
\hline aggregates 8-16 mm & 910 & 910 & 910 & 910 & 910 \\
\hline $\begin{array}{c}\text { plasticizer Mapei } \\
\text { Dynamon SX }\end{array}$ & 5.3 & 5.3 & 5.3 & 5.3 & 5.3 \\
\hline water & 160 & 160 & 160 & 160 & 160 \\
\hline
\end{tabular}


Table 2: Chemical composition of cement.

\begin{tabular}{|c|c|}
\hline Component & Amount [\%] \\
\hline $\mathrm{SiO}_{2}$ & 21.89 \\
\hline $\mathrm{Al}_{2} \mathrm{O}_{3}$ & 5.60 \\
\hline $\mathrm{Fe}_{2} \mathrm{O}_{3}$ & 3.75 \\
\hline $\mathrm{CaO}$ & 62.33 \\
\hline $\mathrm{MgO}$ & 1.04 \\
\hline $\mathrm{K}_{2} \mathrm{O}$ & 0.92 \\
\hline $\mathrm{Na}_{2} \mathrm{O}$ & 0.11 \\
\hline $\mathrm{TiO}_{2}$ & 0.30 \\
\hline $\mathrm{P}_{2} \mathrm{O}_{5}$ & 0.17 \\
\hline $\mathrm{SO}_{3}$ & 2.88 \\
\hline
\end{tabular}

Table 3: Chemical composition of fine-ground ceramics.

\begin{tabular}{|c|c|}
\hline Component & Amount [\%] \\
\hline $\mathrm{SiO}_{2}$ & 63.45 \\
\hline $\mathrm{Al}_{2} \mathrm{O}_{3}$ & 13.98 \\
\hline $\mathrm{Fe}_{2} \mathrm{O}_{3}$ & 5.39 \\
\hline $\mathrm{TiO}_{2}$ & 0.77 \\
\hline $\mathrm{CaO}$ & 8.18 \\
\hline $\mathrm{K}_{2} \mathrm{O}$ & 2.43 \\
\hline $\mathrm{Na}_{2} \mathrm{O}$ & 0.90 \\
\hline $\mathrm{SO}_{3}$ & 0.10 \\
\hline
\end{tabular}

properties -5 specimens $50 \times 50 \times 20 \mathrm{~mm}$, thermal properties -3 specimens $70 \times$ $70 \times 70 \mathrm{~mm}$.

\section{Experimental methods}

\subsection{Compressive and bending strength}

The measurement of compressive and bending strength was done by the electromechanical testing device VEB WPM Leipzig $3000 \mathrm{kN}$ having a stiff 
loading frame with the capacity of $3000 \mathrm{kN}$. The tests were performed according to ČSN EN 12390-3 [5].

\subsection{Basic physical parameters}

Among the basic properties, the bulk density, matrix density and open porosity were measured using the gravimetric method and water vacuum saturation method [6]. Each sample was dried in a drier to remove majority of the physically bound water. After that, the samples were placed into the desiccator with deaired water. During three hours, air was evacuated with vacuum pump from the desiccator. The specimen was then kept under water not less than 24 hours.

\subsection{Water transport properties}

The water sorptivity was measured using a standard experimental setup [7]. The specimen was water and vapour-proof insulated on four lateral sides and the face side was immersed 1-2 $\mathrm{mm}$ in the water. Constant water level in tank was achieved by a Mariotte bottle with two capillary tubes. One of them, inside diameter $2 \mathrm{~mm}$, was ducked under the water level, second one, inside diameter 5 $\mathrm{mm}$, was above water level. The automatic balance allowed for recording the increase of mass. The water absorption coefficient $A\left[\mathrm{kgm}^{-2} \mathrm{~s}^{-1 / 2}\right]$ was calculated using the formula

$$
i=A \cdot \sqrt{t}
$$

where $i\left[\mathrm{~kg} / \mathrm{m}^{2}\right]$ is the cumulative water absorption, $t$ is the time from the beginning of the suction experiment. The water absorption coefficient was then used for the calculation of the apparent moisture diffusivity in the form [8]

$$
\kappa_{a p p} \approx\left(\frac{A}{w_{c}-w_{0}}\right)^{2}
$$

where $w_{c}$ is the saturated moisture content $\left[\mathrm{kgm}^{-3}\right]$ and $w_{0}$ the initial moisture content $\left[\mathrm{kgm}^{-3}\right]$.

\subsection{Thermal properties}

Thermal conductivity $\lambda\left[\mathrm{W} \mathrm{m}{ }^{-1} \mathrm{~K}^{-1}\right]$ and specific heat capacity $c\left[\mathrm{~J} \mathrm{~kg}^{-1} \mathrm{~K}^{-1}\right]$, were measured using the commercial device ISOMET 2104 (Applied Precision, Ltd.). The measurement is based on analysis of the temperature response of the analyzed material to heat flow impulses. The heat flow is induced by electrical heating using a resistor heater having a direct thermal contact with the surface of the sample. 


\section{Experimental results and discussion}

\subsection{Compressive and bending strength}

Table 4 shows the mechanical properties of five studied concretes. The replacement of Portland cement by find-ground ceramics up to $20 \%$ of mass did not lead to any significant decrease in compressive strength; the decrease of bending strength was lower than $15 \%$ which was still acceptable. For the replacement level higher than $20 \%$ of the mass of cement, the compressive strength was affected to a much higher extent than the bending strength. For RC60 the compressive strength was three times lower as compared with the reference concrete mixture but the bending strength was only $30 \%$ lower. In any case, as for the mechanical properties, the concretes with $40 \%$ of fine-ground ceramics and more did not meet the basic criteria to be considered high performance materials.

A comparison with similar HPC containing metakaolin [9] showed that for the same amount of Portland cement replacement the compressive strength of HPC with fine-ground ceramics was 5\% lower and bending strength $35 \%$ lower. However, also the mechanical properties of reference HPC from [9] were better than $\mathrm{RC}$ in this paper so that this comparison did not present a convincing argument that metakaolin as cement replacement was a more successful solution than the application of fine-ground ceramics.

\subsection{Basic physical parameters}

The bulk density of the analyzed concretes (Table 5) decreased with the increasing amount of fine-ground ceramics; the open porosity increased in the corresponding way. The values of matrix density were almost the same (within a 3\% limit) for all studied concretes. For up to $20 \%$ replacement of Portland cement the obtained results were very similar with metakaolin concrete from [9].

Table 4: Mechanical properties of the studied concretes.

\begin{tabular}{|l|c|c|}
\hline \multirow{2}{*}{ Material } & \multicolumn{2}{|c|}{ Strength [MPa] } \\
\cline { 2 - 3 } & Compressive & Bending \\
\hline RC & 62.0 & 8.44 \\
\hline RC10 & 65.7 & 7.69 \\
\hline RC20 & 60.2 & 7.11 \\
\hline RC40 & 42.6 & 6.55 \\
\hline RC60 & 22.5 & 5.69 \\
\hline
\end{tabular}


Table 5: $\quad$ Basic physical properties of the studied concretes.

\begin{tabular}{|l|c|c|c|}
\hline \multirow{2}{*}{ Material } & $\rho_{\mathrm{b}}$ & $\rho_{\text {mat }}$ & $\psi$ \\
\cline { 2 - 4 } & {$\left[\mathrm{kg} \mathrm{m}^{-3}\right]$} & {$\left[\mathrm{kg} \mathrm{m}^{-3}\right]$} & {$[\%]$} \\
\hline $\mathrm{RC}$ & 2400 & 2690 & 10.7 \\
\hline $\mathrm{RC} 10$ & 2370 & 2710 & 12.6 \\
\hline $\mathrm{RC} 20$ & 2310 & 2630 & 13.0 \\
\hline $\mathrm{RC} 40$ & 2270 & 2660 & 14.0 \\
\hline $\mathrm{RC} 60$ & 2270 & 2650 & 14.5 \\
\hline
\end{tabular}

Table 6: $\quad$ Water transport properties of the studied concretes.

\begin{tabular}{|c|c|c|}
\hline \multirow{2}{*}{ Material } & $\mathrm{A}$ & $\kappa$ \\
\cline { 2 - 3 } & {$\left[\mathrm{kg} \mathrm{m}^{-2} \mathrm{~s}^{-1 / 2}\right]$} & {$\left[\mathrm{m}^{2} \mathrm{~s}^{-1}\right]$} \\
\hline $\mathrm{RC}$ & 0.0041 & $1.321 \mathrm{E}-09$ \\
\hline $\mathrm{RC} 10$ & 0.0067 & $3.794 \mathrm{E}-09$ \\
\hline $\mathrm{RC} 20$ & 0.0077 & $3.825 \mathrm{E}-09$ \\
\hline $\mathrm{RC} 40$ & 0.0101 & $6.225 \mathrm{E}-09$ \\
\hline $\mathrm{RC} 60$ & 0.0104 & $5.212 \mathrm{E}-09$ \\
\hline
\end{tabular}

\subsection{Water transport properties}

The results of water sorptivity measurements are presented in Table 6. They were in a very good qualitative agreement with the open porosity data (Table 5). The liquid water transport parameters systematically increased with the increasing amount of fine-ground ceramics in the mix. This is a negative trend, in general. However, in a comparison with common HPC containing silica fume [10] the values of water sorptivity of concretes with fine-ground ceramics were for up to $20 \%$ replacement of Portland cement lower. HPC containing metakaolin [9] with the same level of Portland cement replacement had the water sorptivity effectively the same as HPC with fine-ground ceramics in this paper (the difference was within a 5\% limit which was within the error range of the measuring method). Therefore, similarly as with the mechanical parameters, RC20 appeared as the most suitable mix design.

\subsection{Thermal properties}

The values of thermal conductivity of studied concretes in dry state (Table 7) were in a basic qualitative agreement with open porosity results (Table 5); the 
Table 7: $\quad$ Thermal properties of the studied concretes in dry state.

\begin{tabular}{|l|c|c|}
\hline \multicolumn{1}{|c|}{ Material } & $\lambda\left[\mathrm{Wm}^{-1} \mathrm{~K}^{-1}\right]$ & $\mathrm{c}\left[\mathrm{Jkg}^{-1} \mathrm{~K}^{-1}\right]$ \\
\hline $\mathrm{RC}$ & 1.69 & 691 \\
\hline $\mathrm{RC} 10$ & 1.53 & 678 \\
\hline $\mathrm{RC} 20$ & 1.57 & 705 \\
\hline RC40 & 1.53 & 783 \\
\hline RC60 & 1.41 & 768 \\
\hline
\end{tabular}

thermal conductivity decreased with the increasing amount of replacement of Portland cement by fine-ground ceramics. The values of specific heat capacity increased with the increasing amount of fine-ground ceramics; the maximum difference was $13 \%$, as compared with the reference HPC. The obtained data were in basic agreement with previous measurements of thermal properties of HPC [10-12].

\section{Conclusions}

Experimental results presented in this paper confirmed that find-ground ceramics can be considered an environmental friendly binder with a potential to replace a part of Portland cement in concrete in building industry. However, it was shown that although it was desirable from both environmental and economical point of view to use its highest possible amounts in concrete production, the extent of Portland cement replacement which could be chosen in preparation of high performance concrete mixes had certain limitations.

The main limiting parameter for using higher amounts of fine-ground ceramics in HPC was found the compressive strength. For higher replacement levels than $20 \%$ of mass of cement the compressive strength decreased very fast and the produced concrete lost its high performance character. The water transport parameters increased with increasing amount of fine-ground ceramics in the mix but the increase was not that steep as the decrease in compressive strength. For $20 \%$ Portland cement replacement the water sorptivity was still relatively low and quite acceptable from the point of view of concrete durability. Therefore, concrete with the replacement of Portland cement by fine-ground ceramics in the amount of $20 \%$ by mass was the most suitable solution among the mixes analyzed in this paper.

\section{Acknowledgement}

This research has been supported by the Czech Science Foundation, under grant No P104/10/0355. 


\section{References}

[1] Sabir, B.B., Wild, S., \& Bai, J., Metakaolin and calcined clays as pozzolans for concrete: a review. Cement and Concrete Composites, 23, pp. 441-454, 2001.

[2] Goncalves, J.P., Use of ceramic industry residuals in concrete. REMRevista Escola de Minas, 60, pp. 639-644, 2007.

[3] Lavat, A.E., Trezza, M.A., \& Poggi, M., Characterization of ceramic roof tile wastes as pozzolanic admixture. Waste Management, 29, pp. 16661674, 2009.

[4] Toledo Filho, R.D., Goncalves, J.P., Americano, B.B. \& Faibraim, E.M.R., Potential for use of crushed waste calcined-clay brick as a supplementary cementitious material in Brazil. Cement and Concrete Research, 37, pp. 1357-1365, 2007.

[5] ČSN EN 12390-3, Testing of hardened concrete - Part 3: Compressive strength, Czech Standardization Institute: Prague, 2002.

[6] Roels, S., Carmeliet, J., Hens, H., Adan, O., Brocken, H., Černý, R., Pavlík, Z., Hall, C., Kumaran, K., Pel, L. \& Plagge, R., Interlaboratory Comparison of Hygric Properties of Porous Building Materials. Journal of Thermal Envelope and Building Science, 27, pp. 307-325, 2004.

[7] Vejmelková, E., Pavlíková, M., Jerman, M. \& Černý, R. Free Water Intake as Means of Material Characterization. Journal of Building Physics, 33, pp. 29-44, 2009.

[8] Kumaran, M.K., Moisture diffusivity of building materials from water absorption measurements. Journal of Thermal Envelope and Building Science, 22, pp. 349-355, 1999.

[9] Vejmelková E., Pavlíková, M., Keppert, M., Keršner, Z., Rovnaníková, P., Ondráček, M., Sedlmajer, M., Černý, R., High performance concrete with Czech metakaolin: Experimental analysis of strength, toughness and durability characteristics. Construction and Building Materials, 2010, doi:10.1016/j.conbuildmat.2010.01.017.

[10] Vejmelková, E., Padevět, P., Černý, R., Effect of Cracks on Hygric and Thermal Characteristics of Concrete. Bauphysik, 30, pp. 438-444, 2008.

[11] Toman, J., Černý, R., Thermal Conductivity of High Performance Concrete in Wide Temperature and Moisture Ranges. Acta Polytechnica, 41, pp.8-10, 2001.

[12] Toman, J., Černý, R., Temperature and Moisture Dependence of the Specific Heat of High Performance Concrete. Acta Polytechnica, 41, pp. 57, 2001. 